THE INTERNATIONAL

REVIEW OF RESEARCH IN

OPEN AND DISTANCE LEARNING

\title{
Using Self-Efficacy to Assess the Readiness of Nursing Educators and Students for Mobile Learning
}
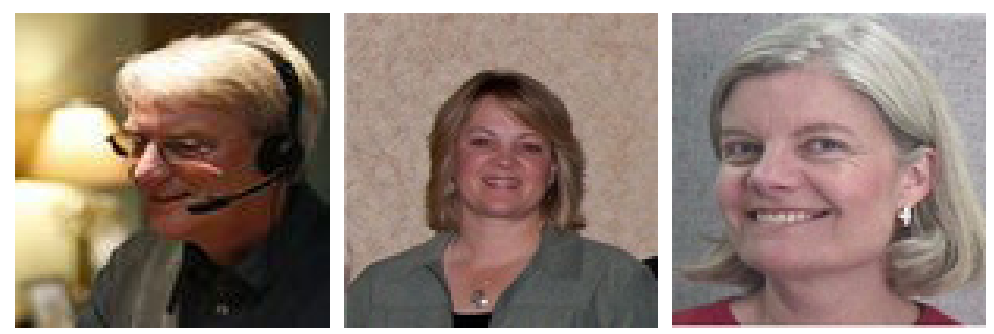

Richard F. Kenny (left) and Caroline L. Park (right) Athabasca University, Canada Jocelyne M. C. Van Neste-Kenny and Pamela Burton (middle) North Island College, Canada Adnan Qayyum University of Ottawa, Canada

\section{Abstract}

The purpose of this study was to assess the self-efficacy of nursing faculty and students related to their potential use of mobile technology and to ask what implications this technology has for their teaching and learning in practice education contexts. We used a cross-sectional survey design involving students and faculty in two nursing education programs in a western Canadian college. In January, 2011, 121 faculty members and students completed the survey. Results showed a high level of ownership and use of mobile devices among our respondents. The median mobile self-efficacy score was 75 on a scale of 100, indicating that both faculty and students were highly confident in their use of mobile technologies and prepared to engage in mobile learning.

Keywords: Self-efficacy; motivation; mobile learning; nursing education; nursing practice education

Previously, we (Kenny, Park, Van Neste-Kenny, Burton, \& Meiers, 2009a, 2009b; Park, Van Neste-Kenny, Burton, \& Kenny, 2010) argued that mobile learning (m-learning) could be effective to support the teaching and learning of nursing students at a distance. We subscribe to Koole's definition (2009; Koole, McQuilkin, \& Ally, 2010) of m-learning: It is a process resulting from the interaction of mobile technologies, human learning capacities, and the social aspects of learning. In the nursing education context, m-learning supports more situated, experiential, and contextualized learning and affords the use of up-to-date and accurate information (Kukulska-Hulme \& Traxler, 2005). Particularly in nursing practice education (clinical courses), m-learning has the potential to bring instructors, peers, and resources together virtually at the point-of-care to support students' safety and evi- 
dence-informed practice (Park et al., 2010).

The purpose of this study was to gauge nursing faculty and students' current use of mobile devices in their teaching and learning and to measure their mobile self-efficacy as an indicator of their readiness to engage in m-learning in the future. As such, this is a replication, on a larger scale, of a previous study (Kenny, Park, Van Neste-Kenny, \& Burton, 2010). As before, we were interested in our respondents' level of motivation to engage in m-learning and, specifically, in the concept of self-efficacy (Bandura, 1997) as applied to mobile learning in nursing education.

Self-efficacy refers to the personal beliefs individuals have that they are capable of learning and performing particular behaviors and is domain-specific (Bandura, 1997; Schunk, 2008). Students' perceptions of self-efficacy have been found to influence their decisions about the choice of activity in which they engage, their emotional responses (e.g., stress and anxiety) when performing the behaviors, and their persistence in carrying out these actions (Bandura, 1997; Compeau \& Higgins, 1995; Schunk, 2008). In the m-learning domain, mobile use is both enabled and constrained by the physical and functional components of the specific devices. They are the medium through which learners interact and therefore impact their physical and psychological comfort levels (Koole, 2009). These components directly impact device usability and therefore an individual's ability to use her mobile device to engage in cognitive tasks, locate and manipulate information, and communicate and collaborate using social technologies (e.g., text messaging, email, or audio conferencing). In an m-learning context, these applications allow learners to interact in social and learning communities where they can acquire information and negotiate meaning. The ensemble of these components then defines the m-learning process and domain.

Individuals' self-efficacy judgments differ on three interrelated dimensions: magnitude, strength, and generalizability (Bandura, 1997, 2006; Compeau \& Higgins, 1995). Magnitude refers to the level of task difficulty individuals believe they can attain. Those with high mobile self-efficacy would believe they were able to use their mobiles to accomplish difficult and sophisticated tasks, while those with low mobile self-efficacy would think they were only able to use them for limited and simple tasks. Self-efficacy strength refers to the level of confidence individuals have in their ability to perform specific tasks (e.g., their level of confidence in their ability to easily learn and use the various features of, and applications provided by, mobile devices). Finally, self-efficacy generalizability reflects how much an individual's judgment is limited to a particular domain of activity. Individuals with high mobile self-efficacy generalizability expect to be able to competently use a variety of different devices, while those with low computer self-efficacy generalizability may perceive their capabilities as limited to particular devices, especially those with which they have had experience.

While a significant body of research exists on learners' feelings of self-efficacy concerning computer technology, online learning, and even podcasting (e.g., Compeau \& Higgins, 1995; Hodges, Stackpole-Hodges, \& Cox, 2008; Johnson, 2005; Kao \& Tsai, 2009; Koh \& Frick, 2009; Liang \& Wu, 2010; Loftus, 2009), this concept does not appear to have been 
examined in any detail in a mobile learning context.

\section{Method}

This study then replicates and extends our previous research (Kenny, Park, Van Neste-Kenny, \& Burton 2010) to gauge the current use of mobile devices by nursing faculty and students in their teaching and learning and to assess their readiness to engage in m-learning by measuring their mobile self-efficacy. Our research questions were as follows:

- In what ways are faculty and students currently using personal mobile devices in their teaching and learning?

- How do they foresee using personal mobile devices in teaching and learning in the future?

- To what degree is the level of mobile self-efficacy of nursing faculty and students related to their potential use of m-technology in teaching and learning?

To investigate these questions, we used a cross-sectional survey design involving students and faculty in two separate nursing education programs at a community college in western Canada: a one-year Practical Nurse (PN) program and a four-year Bachelor of Science in Nursing (BSN) program. At the time of the survey, there were 55 students and 9 faculty members in the PN program and 134 students and 18 faculty members in the BSN Program, for a total of 216 potential participants.

We used an online survey to gather demographic information and mobile use data (see Appendix A) and to administer the mobile use self-efficacy questionnaire (see Appendix B). The demographics and mobile use questions were both quantitative and qualitative in nature. Questions 3 to 6 afforded respondents the opportunity to provide open-ended written comments in addition to the scaled items, while questions 7 to 9 asked only for open-ended responses.

Bandura (1997, 2006) stresses that self-efficacy should measure judgments of capability that may vary across specific realms of activity. Our mobile self-efficacy questionnaire was based on a computer self-efficacy instrument (Compeau \& Higgins, 1995) modified for a mobile learning context. This consisted of changing the question stem for students from "I could complete the job using the software package ..." to "If I had a mobile device such as a smartphone or $3 \mathrm{G}$ phone (e.g., iPhone), I could use it in my Nursing program ..." For instance, the wording for students in question 1 was, "If I had a mobile device such as a smartphone or $3 \mathrm{G}$ phone (e.g., iPhone), I could use it in my Nursing program if there was no one around to tell me what to do as I go." See Appendix A for the full set of questions. Bandura (2006) describes the assessment of self-efficacy as follows:

In the standard methodology for measuring self-efficacy beliefs, individuals are presented with items portraying 
different levels of task demands, and they rate the strength of their belief in their ability to execute the requisite activities. They record the strength of their efficacy beliefs on a 100-point scale, ranging in 10-unit intervals from o ("Cannot do"); through intermediate degrees of assurance, 50 ("Moderately certain can do"); to complete assurance, 100 ("Highly certain can do"). (p. 312)

As stipulated by Bandura, we asked our respondents to express their confidence about mobile use behavior by answering 10 questions, each rated from o to 10 . If their answer was "No" ("Could not do"), they selected "o." If their answer was "Yes," they chose between 1 and 10, with " 1 " indicating only slight confidence and "10" showing total confidence ("Highly certain could do"). Therefore, the scale ranges from a minimum of o to a maximum of 100. Nursing students and instructors scoring o believe that they are essentially incapable of learning and using mobile devices in their teaching and learning, and those scoring 100 believe they are highly certain of their ability to learn and use mobile devices for this purpose. Bandura (2006) also stresses the need for item homogeneity within a domain-relevant scale. Cronbach's alpha was 0.941, indicating that the mobile version of the scale could be considered strongly internally consistent.

\section{Factor Analysis}

An exploratory factor analysis was also conducted to see if the mobile self-efficacy questions as modified for this study might be grouped together and, if so, in what way. An oblique rotation was chosen to ensure that only the unique relationship between each factor and observed item was included in the model. The resulting pattern matrix yielded two factors with eigenvalues greater than 0.7 (ranging from 6.65 to 0.92) and before the scree plot flatlined (see Table 1). The two factors were "external resources" and "using the mobile device alone"; they accounted for over three-quarters of variance in the measure (75.64\%). These factors can be interpreted as aspects of our participants' perceived strength of self-efficacy about mobile device use in their teaching and learning. Both reflect their self-confidence in the use of the various feature applications provided by their mobile devices. However, it is reasonable to assume that participants might feel more self-confident if they received some support in their learning from others or external sources on their devices, rather than relying solely on themselves. 
Table 1

Pattern Matrix of Mobile Self-Efficacy Items

\begin{tabular}{|c|c|c|c|c|c|}
\hline \multirow[b]{2}{*}{ Item } & \multirow{2}{*}{\multicolumn{3}{|c|}{$\begin{array}{l}\text { If I had a mobile device such as a smartphone or } 3 G \text { phone (e.g., iPhone), I } \\
\text { could use it in my Nursing instruction... }\end{array}$}} & \multicolumn{2}{|c|}{$\underline{\text { Factor loading }}$} \\
\hline & & & & $\begin{array}{l}\text { External } \\
\text { resources } \\
\text { available }\end{array}$ & $\begin{array}{l}\text { Using } \\
\text { mobile } \\
\text { by self }\end{array}$ \\
\hline 9 & if someone sho & ne how to do it & & 1.006 & \\
\hline 7 & if I had a lot of & o complete the & hich the device was provided. & 0.949 & \\
\hline 10 & if I had used sil & devices before $t$ & do the same task. & 0.879 & \\
\hline 6 & if someone else & nelped me get $\mathrm{s}$ & & 0.874 & \\
\hline 5 & if I could call sc & e for help if I g & & 0.666 & \\
\hline 4 & if I had seen so & e else using it $b$ & ng it myself. & 0.660 & \\
\hline 8 & if I had just the & -in help facility & ance. & 0.599 & \\
\hline 1 & if there was no & round to tell m & do as I go. & & 0.925 \\
\hline 2 & even if I had ne & sed a device lik & & & 0.852 \\
\hline 3 & if I had only the & ce manual for $r$ & & & 0.669 \\
\hline Factor & Eigenvalues & $\%$ of variance & Cumulative \% & & \\
\hline 1 & 6.649 & 66.49 & 66.49 & & \\
\hline 2 & 0.915 & 9.15 & 75.64 & & \\
\hline
\end{tabular}

Rotation Method: Oblimin with Kaiser Normalization

\section{Results}

\section{Demographic Information}

In January 2011, 121 faculty members and students completed the survey for an overall response rate of $56 \%$. Table 2 provides the breakdown of respondents by program type, status as faculty or student, and gender. 
Table 2

Demographic Information

\begin{tabular}{llcc}
\hline Factor & Grouping & $N$ & $\%$ \\
\hline Program & PN & 38 & 31.4 \\
& BSN & 83 & 68.6 \\
\multirow{2}{*}{ Status } & Faculty & 17 & 14.0 \\
& Student & 104 & 86.0 \\
\multirow{2}{*}{ Gender } & Male & 12 & 9.9 \\
& Female & 109 & 90.1 \\
\hline
\end{tabular}

The BSN program was much larger than the PN program and provided over two-thirds of the respondents in this study. Ninety percent were female, while slightly fewer than $10 \%$ were male.

Table 3

Age Data by Program

\begin{tabular}{llllll}
\hline Status-Year & $N$ & Mean & Min. & Max. & Skew \\
\hline BSN students year 1 & 23 & 27.17 & 19 & 43 & .800 \\
BSN students year 2 & 21 & 24.90 & 20 & 50 & 2.841 \\
BSN students year 3 & 16 & 28.69 & 21 & 52 & 1.293 \\
BSN students year 4 & 11 & 32.64 & 22 & 49 & .779 \\
PN students & 33 & 34.39 & 19 & 53 & .092 \\
Regular faculty & 14 & 50.50 & 43 & 61 & .331 \\
Sessional faculty & 3 & 41.00 & 31 & 50 & -.467 \\
\hline Totals & 121 & 32.49 & 19 & 61 & .599 \\
\hline
\end{tabular}

PN students were substantially older than the BSN students on average and more uniform in age. The mean ages of the BSN students varied from an average of about 25 in the year 2 group to nearly 33 in the year 4 group. Overall, our student respondents tended to be mature adults.

\section{Mobile Ownership and Use}

The familiarity of ownership should impact users' assessments of their capability to use a mobile device and, therefore, mobile self-efficacy scores. Only 10 of our respondents (8\%), 
two faculty members and eight students, indicated that they did not own a mobile device. Table 4 shows which mobiles our respondents owned. About $15 \%$ owned a classic (phone only) mobile, while $27 \%$ had a phone with a camera or MP3 player. Twenty-two percent possessed a smartphone (e.g., a Blackberry), while $24 \%$ had a $3 \mathrm{G}$ phone (e.g., an Apple iPhone). Just under 12\% had "other" devices (such as an Apple iPod Touch or iPad), which provided them with email, Internet access, and nursing applications.

Among students, the types of devices owned were relatively uniform across program groups. Twenty-eight percent of BSN students and 30\% of PN students owned a mobile phone with a camera, while $24 \%$ of BSN students and $27 \%$ of PN students had a $3 \mathrm{G}$ phone. Faculty had a lower level of ownership with $11 \%$ owning a camera phone and $15 \%$ possessing a $3 \mathrm{G}$ phone.

To explain their mobile self-efficacy, it was also important to detail how faculty and students used their devices in their daily lives as well as in teaching and learning. Table 5 shows which mobile features our respondents used weekly. Not surprisingly, the majority (83\%) of respondents used the telephone function of their mobiles the most.

Table 4

Type of Mobile Owned

\begin{tabular}{|c|c|c|c|c|c|c|}
\hline & \multicolumn{5}{|c|}{ Mobile type } & \multirow[b]{2}{*}{ Total } \\
\hline & $\begin{array}{c}\text { Classic } \\
\text { cell }\end{array}$ & $\begin{array}{c}\text { Cell / } \\
\text { camera }\end{array}$ & $\begin{array}{l}\text { Smart- } \\
\text { phone }\end{array}$ & $3 \mathrm{G}$ phone & Other & \\
\hline BSN students year 1 & 7 & 4 & 4 & 7 & 1 & 23 \\
\hline \multirow{2}{*}{ BSN students year 2} & 2 & 8 & 8 & 3 & $\mathrm{O}$ & 21 \\
\hline & 2 & 6 & 3 & 4 & 1 & 16 \\
\hline BSN students year 3 & o & 2 & 5 & 3 & 1 & 11 \\
\hline \multirow[t]{2}{*}{ BSN students year 4} & 3 & 10 & 3 & 9 & 8 & 33 \\
\hline & 3 & 3 & 4 & 2 & 2 & 14 \\
\hline PN students & 1 & $\mathrm{O}$ & $\mathrm{O}$ & 1 & 1 & 3 \\
\hline \multicolumn{7}{|l|}{ Sessional faculty } \\
\hline Total & 18 & 33 & 27 & 29 & 14 & 121 \\
\hline
\end{tabular}

The number was not $100 \%$ because some respondents indicated that they used their mobiles for emergency purposes only, and others may have tended to text more than telephone since text messaging (SMS) was the second most widely used feature at $72 \%$. Just under half (45\%) of our respondents used their mobiles weekly to browse the Internet, while over 
one-third used them for photography (37\%) or email (36\%), and $21 \%$ to play games. Other uses included recording videos in the lab, listening to music, using the address book, alarm clock, and calendar features, and keeping memos and lists.

Table 5

Mobile Device Features Used at Least Once a Week

\begin{tabular}{cccccccccccc}
\hline Program & $\begin{array}{c}\text { Faculty- } \\
\text { Student }\end{array}$ & Telephone & Camera & Email & Browser & SMS & $\begin{array}{c}\text { Audio } \\
\text { msg. }\end{array}$ & $\begin{array}{c}\text { Word } \\
\text { pro. }\end{array}$ & $\begin{array}{c}\text { Health } \\
\text { apps. }\end{array}$ & Games & Other \\
\hline BSN & Faculty & 8 & 2 & 6 & 6 & 7 & 0 & 1 & 1 & 1 & 3 \\
& Student & 65 & 31 & 28 & 34 & 56 & 4 & 6 & 9 & 20 & 12 \\
PN & Faculty & 4 & 1 & 1 & 1 & 2 & 0 & 0 & 1 & 0 & 1 \\
& Student & 24 & 11 & 9 & 13 & 22 & 5 & 4 & 4 & 4 & 2 \\
\hline Totals & & 101 & 45 & 44 & 54 & 87 & 9 & 11 & 15 & 25 & 18 \\
\hline
\end{tabular}

We also asked which features respondents used at least once weekly to support their learning or teaching (Table 6), and they reported this use to be about $65 \%$ of their total mobile use. Fifty-four percent used the mobile for educational purposes, while 39\% used their devices for browsing and texting, and $30 \%$ for email. It was surprising that only $17 \%$ of this sample reported using their mobiles for health applications since in our previous research (Kenny, Park, Van Neste-Kenny, Burton, \& Meiers, 2009a), nursing students rated drug reference programs as the most useful mobile feature.

Table 6

Mobile Features Used in Nursing Education by Program

\begin{tabular}{lccccccccccc}
\hline Program & $\begin{array}{l}\text { Faculty- } \\
\text { Student }\end{array}$ & Telephone & Camera & Email & Browser & SMS & $\begin{array}{c}\text { Audio } \\
\text { msg. }\end{array}$ & $\begin{array}{c}\text { Word } \\
\text { pro. }\end{array}$ & $\begin{array}{c}\text { Health } \\
\text { apps. }\end{array}$ & Games & Other \\
\hline BSN & Faculty & 4 & 0 & 3 & 4 & 4 & 0 & 1 & 1 & 0 & 2 \\
& Student & 44 & 12 & 24 & 28 & 32 & 1 & 8 & 11 & 0 & 8 \\
\multirow{2}{*}{ PN } & Faculty & 3 & 0 & 1 & 1 & 0 & 0 & 0 & 1 & 0 & 0 \\
& Student & 14 & 7 & 8 & 14 & 11 & 3 & 5 & 7 & 2 & 4 \\
\hline Totals & & 65 & 19 & 36 & 47 & 47 & 4 & 4 & 20 & 2 & 14 \\
\hline
\end{tabular}

\section{The Potential Use of Mobile Devices in Teaching and Learning}

In the demographics section of the survey, we asked our respondents to answer an openended question: "What do you see as the potential uses of these technologies to support teaching and learning in the practice area?" They made a wide range of comments about the use of mobile devices in their teaching and learning. The two major themes that emerged from this data were, perhaps not surprisingly, the benefits of and barriers to the use of mo- 
bile devices perceived by the faculty and students in both nursing programs.

\section{Benefits.}

One major benefit noted by faculty and students for their teaching and learning was the use of mobile devices to provide quick, easy, and anytime access to current professional information at the point-of-care. This included both the use of nursing resource applications such as drug guides and access to the Internet. This perceived importance of mobiles as a way to access resources is also supported by past research and our own studies (Kenny, Park, Van Neste-Kenny, Burton, \& Meiers, 2009a, 2009b). These comments by BSN students typify the comments made in this regard: "Technology can support nursing practice, such as accessing current information quickly to support practice decisions, reducing errors (i.e., using programs to check drugs and calculate doses)."

And, as another student said,

If downloading is time effective, it can allow for faster access to information without having to track down books or hardcopy resources. The information will be upto-date. It can be accessed from the patient's bedside for teaching and learning based on specific questions by the patient.

The following comment by a PN student corroborated these views:

I think they will help because there is so much that technology like phones are capable of nowadays; Websites, questions we may have, being able to talk to somebody somewhere else quickly without leaving the room, I think there is so much potential to it. Faster responses, and if someone does not know the answer, they can find it.

The other main benefit cited by our respondents was the use of mobile devices to improve communications between faculty and students who are off campus on practice placements, thereby affording students greater access to their instructors. In this regard, one instructor noted that mobile devices could provide

instant communication with students (i.e., texting/ emails) - texting re "checking in" with students who are in indirect supervision (i.e., community placements) using blackboard to send messages to students, receive documents from them (i.e., domains of practice) - use of nursing resource software to support myself and students in the practice setting (i.e., medication software, psychomotor skills, nursing assessment) - access best 
evidence to support practice (i.e., databases to search for information related to practice).

And a BSN student noted that mobile devices could provide "support from teachers, we have two towns primarily that we are sent to for placements, and our instructors may not be immediately available. We could get quick responses and support from them if we had communication on these devices."

\section{Barriers.}

Our respondents also reported on barriers to the use of mobile devices in their teaching and learning. The barriers most widely discussed were the cost of both mobile devices and of wireless connectivity and who should pay for it. For instance, one BSN student stated,

Not all people have these types of devices-they can be costly with roaming time as well-will VIHA [Vancouver Island Health Authority, which runs the local hospitals and clinics] help in paying these bills? Will everyone be expected to have one?

A PN student made a similar observation:

As indicated previously, my only concern is the cost associated. I currently do not maximize the potential of my smartphone simply because the fees to do so are a lot, which is not in the budget of a student.

Our respondents also noted potential barriers pertaining to mobile use in the hospitals. One was a concern about infection control. One BSN faculty member commented, "[I] just wonder about infection control issues with these devices in the clinical setting, I can see this as being an issue, and also wonder if the cleaning products required by the agency would damage the devices?" and a PN student agreed, commenting that, "The word 'sanitary' comes to mind ... if using the phone in the nursing practice, we would have to be aware and practice asepsis technique."

Another concern was about current hospital policies related to mobile use. A BSN faculty member raised this issue as follows:

Hmmmm ... I think we need to inform and educate our colleagues in the agencies about the use of technology, that in fact using a cell phone near a cardiac monitor is not going to upset the monitor, nor will it upset communications, etc., within the hospital particularly. I think this is true, and I think there is a need to assure people that it is not going to get in the way of their practice. 
And, finally, while not a benefit or barrier per se, some faculty members discussed the overall need to adjust their teaching to take into account the mobile technology that students are using in their daily lives. For instance, one BSN faculty member stated that

students are very comfortable with technology these days, and it is very much the norm at breaks and meal times to see them pull out their phones or mobile device and start to text, and so forth. Many students have pointed out applications to me in these settings which they frequently use to support their learning, such as drug guides or "apps" which quickly remind them of vital sign norms, and so forth. I want to understand them and be able to relate on their level. I want to be able to communicate with them and not appear that I don't know. I also want to maintain a sense of where they are at, and without understanding the technology that they use and how this influences their learning, I would feel somewhat of a disconnect. I am not saying that it surpasses other ways of teaching, but for them it is the new "normal," and I must adjust to it to help support/understand them as well as using other teaching/learning techniques.

The last word in this regard went to a PN student, who also expressed the importance of nurses keeping up with emerging technologies in a rapidly changing world. "Since we do live in a technology age that is progressing and changing all the time, we need to keep up with it to provide fast and better care for our clients."

\section{Self-Efficacy}

The demographics data and analysis of the comments made by our participants indicated that they had adopted mobile technologies in their personal lives and appeared to foresee the potential for their use in teaching and learning. Most of our respondents reported owning a mobile device, and most used it at least weekly to make telephone calls. But did this translate into the confidence to use mobile devices in their professional lives? Did their familiarity with mobile use translate into feelings of self-efficacy (SE)?

The average mobile self-efficacy score (Table 7) was 68 out of a possible score of 100. However, these scores were negatively skewed, indicating a tendency toward higher scores with individual low scores affecting the average. Therefore, the median score of 75 is likely more reflective of the group as a whole. 
Table 7

Self-Efficacy Scores - Program Comparison (Faculty-Student Combined)

\begin{tabular}{lccccccc}
\hline Program & $N$ & Mean & Median & Std. Dev. & Min. & Max. & Skew \\
\hline BSN & 83 & 72.16 & 79.00 & 24.523 & 5 & 100 & -1.014 \\
PN & 38 & 58.92 & 64.50 & 29.357 & 0 & 100 & -0.624 \\
Total & 121 & 68.00 & 75.00 & 26.734 & 0 & 100 & -0.898 \\
\hline
\end{tabular}

There was also a substantial difference between programs. BSN students and faculty had a median score over 14 points higher than PN program members (70.00 as opposed to 64.50). An analysis of variance (Table 8) showed the mean self-efficacy scores between programs to be statistically significant at the a $\leq .05$ level.

Table 8

Self-Efficacy (SE) Scores by Program: ANOVA Results

\begin{tabular}{lcccccc}
\hline & & $\begin{array}{c}\text { Sum of } \\
\text { squares }\end{array}$ & $d f$ & Mean & & \\
& square & $F$ & Sig. \\
\hline $\begin{array}{l}\text { SE score } \\
\text { program }\end{array}$ & $\begin{array}{c}\text { Between groups } \\
\text { (combined) }\end{array}$ & 4566.273 & 1 & 4566.273 & 6.692 & 0.011 \\
\hline
\end{tabular}

\begin{tabular}{cccc} 
Within groups & 81197.727 & 119 & 682.334 \\
Total & 85764.000 & 120 & \\
\hline
\end{tabular}

Table 9 compares the mean mobile self-efficacy scores by faculty and student. The mean student self-efficacy scores were higher than those of the faculty, but faculty median scores were higher, indicating that the faculty means were likely affected by an outlier. However, an ANOVA showed no statistically significant differences between the self-efficacy scores of these two groups. 
Table 9

Self-Efficacy Scores: Faculty-Student Comparison

\begin{tabular}{lccccccc}
\hline Faculty-Student & $N$ & Mean & Median & Std. Dev. & Min. & Max. & Skew \\
\hline Faculty & 17 & 62.12 & 80.00 & 35.173 & 0 & 100 & -0.635 \\
Student & 104 & 68.96 & 74.50 & 25.176 & 0 & 100 & -0.913 \\
Total & 121 & 68.00 & 75.00 & 26.734 & 0 & 100 & -0.898 \\
& & & & & & & \\
\hline
\end{tabular}

A Pearson's $r$ correlation between respondents' chronological ages and self-efficacy scores was -0.145. While this mild negative association indicated that respondents' self-efficacy scores tended to be higher for the lower age groups on average, this relationship was not statistically significant.

However, there was a significant positive relationship between the total number of mobile features respondents reporting using and their self-efficacy scores (see Table 10). Pearson's $r$ correlations indicated that those indicating higher numbers of features used tended to also have higher SE scores.

Table 10

Number of Mobile Features Use and Self-Efficacy

Total features used weekly by SE $\quad r=0.391 \quad a \leq .01$

Total features used in program by SE $\quad r=0.368 \quad a \leq .01$

\section{Discussion and Conclusions}

M-learning has the potential to bring instructors, peers, and resources together virtually at the point-of-care to support student safety and evidence-informed practice. This study assessed the current use of mobile technology by faculty and students in nursing education and investigated their predisposition to use this new technology in their teaching and learning.

Our first research question asked how faculty and students were currently using personal mobile devices in their teaching and learning. The results of the demographics portion of our survey revealed that most respondents owned mobile devices and that nearly half (46\%) owned smartphones or $3 \mathrm{G}$ devices. Furthermore, the ownership of these more sophisticated mobiles was spread fairly evenly across all groups and ages. While our respondents 
used their mobiles weekly and predominantly for communications (cell phone, texting, and email), they also used them regularly for a range of other activities, including Web browsing, photography, word processing, and health applications. More importantly, nearly twothirds (65\%) of the time, our respondents used their mobiles in their teaching and learning. This data alone indicates that our respondents are not only predisposed to use mobile devices in nursing education, they have already begun to do so.

Our second research question queried our respondents about their views on using mobile devices in their teaching and learning in the future. If nursing faculty and students are already using these devices in a substantive way, will this use increase? In what ways? This question was addressed most specifically by our respondents' replies to the open-ended question asking for their views about the potential uses of these technologies to support teaching and learning in the practice area. They pointed out both benefits and barriers to such use. Among the benefits were just-in-time access to current, professional information at the point-of-care and improved communications between students and faculty, especially while students are in clinical practice placements. Among the barriers were the cost of purchasing a device and high wireless connectivity costs as well as issues of infection control and adhering to current hospital policies. The implication of these findings is that, despite some significant barriers to use, nursing faculty and students do foresee an increasing use of mobile devices in their practice and strong reasons for their presence.

Finally, we asked, To what degree is the level of mobile self-efficacy among nursing faculty and students related to their potential use of m-technology in teaching and learning? Selfefficacy refers to individuals' personal beliefs that they are capable of learning and performing particular behaviors. The stronger the sense of personal efficacy they possess, the greater their perseverance will be, and the likelihood increases that they will perform the chosen activity successfully (Bandura, 1997; Compeau \& Higgins, 1995). Our results provide some support for this relationship. The mean self-efficacy score for our respondents was 75 , a rating that reflects a high level of confidence in their ability to use mobile technology, that is a strong sense of personal mobile self-efficacy. Moreover, there were strong positive correlations between the magnitude of our respondents' use of mobile device features and their self-efficacy scores. While this data is based on self-report scores rather than independent observations, it does provide support for the conclusion that the more individuals (at least as represented by our respondents) use mobile devices, the more self-confidence they develop in use, resulting in the increased likelihood that they will use the devices even more, forming a positive feedback system.

These self-efficacy levels, however, were significantly different between program groups, with BSN students and faculty having a median difference that was 14 points higher than PN students and faculty. Since the PN students engage in a one-year certificate program while the BSN students are involved in a four-year baccalaureate program, it is possible that higher levels of education and experience could contribute strongly to an individual's sense of mobile self-efficacy in learning contexts. No other comparisons resulted in significant differences. There was no discernible difference in mobile self-efficacy between faculty and students. While there was a slight relationship between age and self-efficacy in favor of 
younger respondents, this correlation was not statistically significant.

Despite the difference between nursing programs, at a median rating of nearly 65 out of 100, even PN students and faculty are demonstrating a strong sense of mobile self-efficacy. While the BSN students and faculty in this institution had a higher level of mobile selfefficacy, the vast majority of our respondents indicated a strong sense of self-confidence in using their mobile devices, and their use of these devices clearly carried over into their teaching and learning.

It appears, then, that nursing faculty and students are quite familiar with the use of mobile technology, and a substantial proportion of them are very comfortable using the various functionalities these devices afford. Therefore, it is reasonable to conclude that nursing students and faculty, as represented by our respondents, are well prepared and strongly motivated to engage in mobile learning. The implication for nursing programs is that there is a substantive reason for them to consider the integration of mobile device use in their curricula, if they have not already done so. Nursing faculty and students are already using such devices in their teaching and learning informally on a regular basis, and this use is only likely to increase.

\section{Future Research}

While the results from this study appear to provide strong evidence that nursing students and faculty are well-disposed to m-learning, these results are from two nursing programs in one rural community college and, as such, need to be corroborated in different settings and at different levels of nursing study. Our research team is currently implementing a replication of this study in baccalaureate and graduate specialty nursing programs in a large urban setting in western Canada.

In addition, while our mobile self-efficacy scale was based on a previously validated computer self-efficacy scale (Compeau \& Higgins, 1995) and its validity is also supported by the results of an exploratory factor analysis, the psychometrics of our current instrument require further assessment. We will carry out a confirmatory factor analysis as a component of our planned replication study. 


\section{References}

Bandura, A. (1997). Self-efficacy: The exercise of control. New York, NY: W. H. Freeman and Company.

Bandura, A. (2006). Guide for constructing self-efficacy scales. In F. Pajares \& T. Urdan (Eds.), Self-efficacy beliefs of adolescents (pp. 307-337). Greenwich, CT: Information Age Publishing.

Compeau, D. R., \& Higgins, C. A. (1995). Computer self-efficacy: Development of a measure and initial test. MIS Quarterly, 19(2), 189-211.

Hodges, C. B., Stackpole-Hodges, C. L., \& Cox, K. M. (2008). Self-efficacy, self-regulation, and cognitive style as predictors of achievement with podcast instruction. Journal of Educational Computing Research, 38(2), 139-153.

Johnson, R. D. (2005). An empirical investigation of sources of application-specific computer-self-efficacy and mediators of the efficacy: Performance relationship. International Journal of Human-Computer Studies, 62(6), 737-758.

Kao, C.-P., \& Tsai, C.-C. (2009). Teachers' attitudes toward web-based professional development, with relation to internet self-efficacy and beliefs about web-based learning. Computers and Education, 53, 66-73.

Kenny, R. F., Park, C. L., Van Neste-Kenny, J. M. C., Burton, P. A., \& Meiers, J. (2009a). Using mobile learning to enhance the quality of nursing practice education. In M. Ally (Ed.), Mobile learning: Transforming the delivery of education and training (pp. 75-98). Edmonton, AB: Athabasca University Press. Retrieved from http:// www.aupress.ca/index.php/books/120155

Kenny, R. F., Park, C. L, Van Neste-Kenny, J. M. C., Burton, P. A., \& Meiers, J. (2009b). Mobile learning in nursing practice education: Applying Koole's FRAME model. Journal of Distance Education, 23(3), 75-96. Retrieved from http://www.jofde. ca/index.php/jde/article/view/599

Kenny, R. F., Park, C. L., Van Neste-Kenny, J. M. C., \& Burton, P. A. (2010). Mobile selfefficacy in Canadian nursing education programs. In M. Montebello, V. Camilleri, \& A. Dingli (Eds.), Proceedings of mLearn 2010, the 9th World Conference on Mobile Learning, Valletta, Malta.

Koh, J. L., \& Frick, T. W. (2009). Instructor and student classroom interactions during technology skills instruction for facilitating preservice teachers' computer self-efficacy. Journal of Educational Computing Research, 4O(2), 211-228.

Koole, M. L. (2009). A model for framing mobile learning. In M. Ally (Ed.), Mobile learning: Transforming the delivery of education and training (pp. 25-47). Edmonton, 
AB: Athabasca University Press. Retrieved from http://www.aupress.ca/index. $\mathrm{php} /$ books $/ 120155$

Koole, M. L., McQuilkin, J. L., \& Ally, M. (2010). Mobile learning in distance education: Utility or futility? Journal of Distance Education, 24(2), 59-82. Retrieved from http://www.jofde.ca/index.php/jde/article/view/644

Kukulska-Hulme, A., \& Traxler, J. (2005). Mobile teaching and learning. In A. KukulskaHulme \& J. Traxler (Eds.), Mobile learning: A handbook for educators and trainers (pp. 25-44). London: Routledge.

Liang, J-C., \& Wu, S-H. (2010). Nurses' motivations for web-based learning and the role of internet self-efficacy. Innovations in Education and Teaching International, 47(1), 25-37.

Loftus, J. (2009). Factors affecting implementation of educational media casting as an instructional resource in distance education (Unpublished master's thesis). Athabasca University, Athabasca, AB. Retrieved from http://library.athabascau.ca/

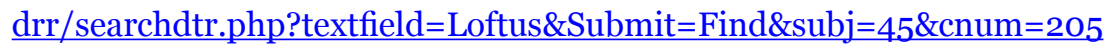

Park, C. L., Van Neste-Kenny, J. M. C., Burton, P. A. \& Kenny, R. F. (2010). A model of mobile faculty presence in nursing education practice. Canadian Journal of Nursing Informatics, 5(3), 21-42. Retrieved from http://cjni.net/Journal original/Summer2010/Park.pdf

Schunk, D.H. (2008) Learning theories: An educational perspective (5th ed.). Upper Saddle Hill, NJ: Pearson Education. 


\section{Appendix A: Demographics and Mobile Use Questions}

1. What is your age?

2. What is your gender?

3. Do you own a mobile device? [single choice with comment]
a. Classic cell phone (telephone only)
b. Classic cell with digital camera and/or MP3 player.
c. Smartphone with email and Internet capability (e.g., Blackberry Bold, HP iPAQ 910)
d. $3 \mathrm{G}$ Phone (with visual desktop and access to an applications "store"; e.g., Apple iPhone, Google Android phone)
e. Other (please explain).
f. I don't own a mobile device.

4. If you own a mobile device, which features do you use at least once a week? [multiple choices with comment]
a. The telephone
b. The digital camera
c. Email
d. Internet Browser
e. Instant text messaging (SMS)
f. Audio Messaging (e.g., Skype, MSN Messenger)
g. Word processing
h. Health applications (e.g., ePocrates)
i. Games
j. Other (please explain).
k. I don't own a mobile device.

5. If you own a mobile device, which features have you used at least one or more times in your Nursing program to support your learning? [multiple choices with comment]
a. The telephone
b. The digital camera
c. Email
d. Internet Browser
e. Instant text messaging (SMS)
f. Audio Messaging (e.g., Skype, MSN Messenger)
g. Word processing 
h. Health applications (e.g., ePocrates)

i. Games?

j. Other (please explain).

k. I have never used my mobile device in my Nursing program.

6. Which kinds of information would you like to be able to share with your students or other instructors via mobile? [multiple choices with comment]

a. Course administration (i.e., meeting times, assignments, absences, etc.)

b. Motivational messages

c. Evaluatory comments

d. Care planning decisions

e. Sharing practice information

f. Sharing interesting Internet links

g. Other

7. What do you see as the potential uses of these technologies to support nursing practice? [open comment]

8. What do you see as the potential uses of these technologies to support teaching and learning in the practice area? [open comment]

9. Please add any further comments or observations about your use of cell phones and other mobile devices that you would like to bring to our attention. [open comment] 


\section{Appendix B: Mobile Self-Efficacy Scale Questions}

If I had a mobile device such as a smartphone or $3 \mathrm{G}$ phone (e.g., iPhone), I could use it in my Nursing instruction...

\begin{tabular}{|c|c|}
\hline Q1 & $\ldots$ if there was no one around to tell me what to do as I go. \\
\hline Q2 & ... even if I had never used a device like it before. \\
\hline Q3 & ... if I had only the device manual for reference. \\
\hline Q4 & ... if I had seen someone else using it before trying it myself. \\
\hline Q5 & ... if I could call someone for help if I got stuck. \\
\hline Q6 & ... if someone else had helped me get started. \\
\hline Q7 & ... if I had a lot of time to complete the task for which the device was provided. \\
\hline Q8 & ... if I had just the built-in help facility for assistance. \\
\hline Q9 & ... if someone showed me how to do it first. \\
\hline Q10 & ... if I had used similar devices before this one to do the same task. \\
\hline
\end{tabular}

\section{Athabasca University $\mathbf{a}$}

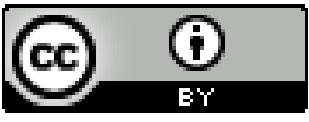

